\title{
Tax Facility Moderates Effect of Inventory Intensity and Capital Intensity on Effective Tax Rate
}

\author{
Sistya Rachmawati \\ \{sistya_r@yahoo.com\} \\ Trisakti University, Indonesia
}

\begin{abstract}
The purpose of this research is to analyze the effect of inventory intensity and capital intensity on effective tax rate, the moderating effect of taxation facility towards the effect of inventory intensity and capital intensity on effective tax rate. Unit analysis is manufacturing company with time horizon 5 years (2015-2019). Secondary data obtained from financial report and annual report of manufacturing company listed on Indonesia Stock Exchange's. Data analysis techniques is Multiple Regression Analysis. Results showed that inventory intensity and capital intensity negatively and significantly influence effective tax rate. Taxation facility is not able to moderate the effect of inventory intensity and capital intensity on effective tax rate. Control variables which are independent commissioner and managerial ownership has no effect on effective tax rate. While control variables which are institutional ownership and external auditor quality has significant effect on effective tax rate.
\end{abstract}

Keywords: Inventory Intensity; Capital Intensity; Taxation Facility; Effective tax rate

\section{Introduction}

The State Revenue and Expenditure Budget states that the biggest source of domestic revenue is taxes. The government provides tax facilities with the aim of improving the country's economy, incentives for reducing tax rates are provided by the government to domestic corporate taxpayers. Thus, by reducing the tax rate to $5 \%$, it is hoped that the company concerned will be more obedient in paying its tax obligations.

The results of the research of Putrid and Lautania and Salaudeen and Akano, show that the intensity of capital and inventory has a negative and significant effect on the effective tax rate [1], [2]. This is because the intensity of capital can increase the depreciation expense in the company so that the company's profit will decrease. Similarly, the intensity of inventory that makes the company must incur costs related to inventory which can result in decreased company profits. In contrast to the research of Putri and Hazir which stated the positive effect of capital intensity on the effective tax rate [3], [4]. This means that the higher the intensity of capital and inventory, the more effective the company's tax rate will be.

Based on the results of the study, it turned out to give contradictory results, which means that there are other variables that have a contingent effect. In connection with this, researchers are motivated to re-examine the research by adding a moderating variable in the form of a tax 
facility variable. This refers to the research of Steven, et al., which shows that the tax facility has a significant positive effect on the effective tax rate [5]. As well as adding control variables in the form of independent commissioners, managerial ownership, institutional ownership, and the quality of external auditors. The reason is that based on Wulansari's research the control variable has a significant positive effect on the effective tax rate [6].

The importance of including control variables in this study is because the control variables have been studied by previous researchers. Thus, the variables that have been studied need to be included as control variables in this study. This is expected to prevent the existence of a missing variable (omitted variable) so that it can overcome biased research results. The research objectives are to determine: (1) The effect of inventory intensity on the effective tax rate, (2) The effect of capital intensity on the effective tax rate, (3) Tax facilities moderate the effect of inventory intensity on the effective tax rate, (4) Tax facilities moderate the effect capital intensity on the effective tax rate.

\section{Theory and Hypothesis Development}

The research results by Salaudeen and Akano and Putri and Lautania, show that inventory intensity has a negative effect on the effective tax rate [1], [2]. Where if the intensity of the company's inventory is high, the tax burden borne by the company is low. Inventory intensity has a negative effect on the effective tax rate, because managers will try to minimize the expenses caused by high inventories so that company profits remain high. Based on the description above, the proposed hypothesis is:

H1: Inventory intensity has a negative effect on the effective tax rate.

Research by Kumalasari and Putri, capital intensity has a positive and significant effect on the effective tax rate [3], [7]. The greater the value of capital intensity indicates the greater the amount of funding or investment transaction activities related to investment in fixed assets and inventories in a company. Companies with large capital will expect large profits as well because of the use of large capital. One of the biggest assets in a company is fixed assets. If the company has large amounts of fixed assets, it will pay large taxes, and vice versa. This is because the contribution of assets is only a few percent. Every year the depreciation value used for tax deductions is the same value, but the income received by the company every year is getting bigger, because large companies automatically have large sales volumes, so large companies even though they have lots of assets will pay large taxes too, because the income earned by the company also big. Based on the description above, the proposed hypothesis is: $\mathrm{H} 2$ : Capital intensity has a positive effect on the effective tax rate.

Referring to previous research, Salaudeen and Akano showed that inventory intensity had a negative effect on the effective tax rate [2]. While the results of research conducted by Rahmawati, the facility of reducing the tax rate by $5 \%$ has a significant negative effect on the effective tax rate [8]. Companies that get reduced rates no longer need to carry out tax management to reduce their tax burden. When the amount of tax paid by the company is no longer burdensome to the company, the company does not need to reduce its tax burden. Based on this explanation, the proposed hypothesis is:

H3: Tax facilities strengthen the effect of inventory intensity on the effective tax rate.

Referring to previous research, Kumalasari and Putri where capital intensity proved to have a positive effect on the Effective tax rate [3], [7]. While the results of research conducted by Rahmawati, the facility of reducing the tax rate by $5 \%$ has a significant negative effect on the effective tax rate [8]. When the amount of tax paid by the company is no longer 
burdensome to the company, the company does not need to do anything to reduce its tax burden. Based on the description above, the proposed hypothesis is:

H4: Tax facilities strengthen the effect of capital intensity on the effective tax rate

\section{Research Method}

The unit of analysis in this research is a manufacturing company. The research sample amounted to 42 companies during the 2015 - 2019 period, thus the number of observations was 210 . The data used in the study was secondary data obtained from the company's annual report. Company sustainability report, company website, and the IDX website "(Indonesian Stock Exchange)." The statistical test tool used is Multiple Linear Regression Analysis.

\subsection{Definition of Operational Variables and Measurement}

\subsubsection{Dependent Variable}

The dependent variable in this study is the effective tax rate, which is an indicator that can assist company management in carrying out tax planning or effective tax planning. Income tax expense with profit before tax. Where the total income tax burden is obtained by adding up the current tax burden with the deferred tax burden. That means the lower the effective tax rate [9]. ETR = Income Tax Expense/Net Profit Before Tax

\subsubsection{Independent Variable}

The independent variable is a variable that causes or affects the dependent variable. In this study the independent variables used are:

a. Capital Intensity means the investment made by the company in the form of fixed assets.

The definition of fixed assets itself is a tangible asset owned by a company whose useful life is more than one year [10]. CAPINT = Total Fixed Assets/Total Assets

b. Inventory Intensity, namely investment activities carried out by the company through inventory levels. Inventory is a must for goods companies and manufacturing companies [5]. INVINT = Inventory/Total Asset

c. Tax Facility is the provision of a tax rate reduction facility of $5 \%$ (five percent) by the government to companies that meet the requirements as stipulated in Law no. 36 of 2008 and Government Regulation No. 81 of 2007 article 2. "With the facility of reducing the tax rate, it is hoped that the company will become more obedient in paying its tax obligations" [5]. A value of 1 (one) is given to companies that get a tariff reduction facility and a value of 0 (zero) to companies that do not get a tariff reduction facility.

\subsubsection{Control Variables}

The importance of putting in control variables in this study is because the control variables have been studied by previous researchers [10]. Therefore, the variables that have been studied need to be included as control variables in this study. This is expected to prevent the existence of a missing variable (omitted variable) so that it can overcome biased research results. The control variables in this study are as follows: 
a. Independent Commissioner. Independent commissioners are commissioners who come from outside the company and do not have internal company relationships. The decision of the directors of the Jakarta Stock Exchange Number Kep-305/BEJ/07-2004 "requires companies whose shares are listed on the Indonesia Stock Exchange (IDX) to have independent commissioners of at least $30 \%$ of all members of the board of commissioners who can be pre-elected through GMS before the listing and becomes effective as an independent commissioner after the shares of the company are listed". That means the more independent commissioners, the better [11]. The results of research by Nilasari and Setiawan show that the Independent Commissioner partially influences the effective tax rate [12]. KI = Number of independent commissioners/board of commissioners

b. Managerial Ownership. Managerial ownership is the amount of share ownership owned by the company's management who oversees carrying out all the company's operational activities. Management in the company can be in the form of a board of commissioners or a board of directors. With managerial ownership, management in a company has dual functions. Management can act as an agent who is responsible for every decision making in the company and as a principal, namely as the owner of the company. That means that the greater the percentage of managerial ownership, it is expected to reduce agency problems that can arise in a company [13]. The results of Putri and Lautania's research stated that managerial ownership has an influence on ETR. MANOWN $=$ Number of management shares/Number of shares outstanding X 100\% [1].

c. Institutional Ownership. According to Wijayanti and Merkusiwati, institutional ownership has an important meaning in monitoring management because institutional ownership is considered capable of monitoring management [14]. The results of Putri and Lautania's research states that institutional ownership has an influence on ETR. INSOWN $=$ Number of Institutional Shares/Number of outstanding shares X 100\% [1].

d. External Auditor Quality. Is to ensure the company's financial statements have been presented correctly and transparently, auditing financial statements by external auditors can assist companies in implementing good corporate governance practices. Public accounting firms (KAP) big four or big four are the four largest accounting service firms worldwide, which in addition to offering audit services also offer tax, management, actuarial, and so on consulting [13].

In a study conducted by Sudaryo, et al., the quality of external auditors has a positive effect on the company's effective tax rate [15]. In line with research where there is a positive relationship between audit quality and the effective tax rate, but not significantly [16]. The quality of external auditors has a positive influence on the effective tax rate, because the company's financial statements audited by the big four KAPs produce higher quality with a high level of transparency to shareholders. Thus, it is expected that the tax that must be paid by the company is in accordance with the actual situation and avoids aggressive tax behavior and only benefits certain parties. A value of 1 is given for large KAPs, namely KAPs that are included in the big four KAPs and a value of 0 for small KAPs.

\subsection{Population and Sample}

The research population is a manufacturing company, the sampling technique uses purposive sampling, namely the sample must comply with the required criteria, namely: (1) Manufacturing companies listed on the Indonesia Stock Exchange and consisted of publish annual reports and sustainability reports in 2015-2019, (2) Manufacturing companies that consistently disclose complete information related to the variables used in the study. 


\subsection{Data analysis method}

Hypothesis testing using multiple regression analysis model with SPSS version 22.0 software. The multiple regression equation used is as follows:

$\mathrm{ETR}=\alpha+\beta 1 \mathrm{IP}+\beta 2 \mathrm{IM}+\beta 3 \mathrm{IP} \cdot \mathrm{EP}+\beta 4 \mathrm{IM} \cdot \mathrm{EP}+\beta 5 \mathrm{KI}+\beta 6 \mathrm{KM}+\beta 7 \mathrm{Kin}+\beta 8 \mathrm{KAE}+\mathrm{e}$

Note : ETR : Effective tax rate; CAPINT : Capital intensity; INVINT : Intensity of inventory; $K I$ : Independent Commissioner; KA : Audit committee; MANOWN : Managerial ownership;INSOWN : Institutional ownership; GOVOWN : Government ownership; FP : Tax facilities; SPEC_REC : Affiliated company transactions; AUD : Quality of external auditors; e: Error

\section{Analysis and Discussion}

\subsection{Descriptive Statistics}

Table 1 is a descriptive statistic, as follows:

Table 1. Descriptive Statistics Test Results

\begin{tabular}{ccccc}
\hline Variable & Min & Max & Mean & Deviation Std. \\
ETR & 0.0138 & 0.8126 & 0.2574 & 0.1141 \\
IP & 0.0355 & 0.4968 & 0.1956 & 0.0954 \\
IM & 0.0338 & 0.9018 & 0.3828 & 0.1752 \\
KI & 0.0000 & 1.0000 & 0.3920 & 0.1296 \\
KM & 0.0000 & 0.6827 & 0.0585 & 0.1178 \\
KEPINS & 0.0194 & 0.9800 & 0.6357 & 0.2122 \\
\hline
\end{tabular}

Note: ETR : Effective tax rate; IP : Inventory Intensity; IM : Capital Intensity; KI : Independent Commission; KM : Managerial Ownership; KEPINS : Institutional Ownership

In table 1 above, the effective tax rate, inventory intensity, capital intensity, and control variables, namely independent commissioners, institutional ownership, have an average value greater than the standard deviation value, meaning that the data are homogeneous, while managerial ownership is smaller than the standard deviation is heterogeneous.

Table 2. Frequency Descriptive Statistics Test Results

\begin{tabular}{clcccc}
\hline \multicolumn{1}{c}{ Variable } & Frequency & Percentage & $\begin{array}{c}\text { Valid } \\
\text { Percentage }\end{array}$ & $\begin{array}{c}\text { Cumulative } \\
\text { Percentage }\end{array}$ \\
\hline \multirow{2}{*}{ FP } & $\begin{array}{l}\text { companies that don't } \\
\text { get a tariff reduction facility } \\
\text { companies that get facilities } \\
\text { tariff reduction }\end{array}$ & 160 & $76.2 \%$ & $76.2 \%$ & $76.2 \%$ \\
KAE & 50 & $23.8 \%$ & $23.8 \%$ & $100.0 \%$ \\
Small KAP & 145 & $69.0 \%$ & $69.0 \%$ & $69.0 \%$ \\
Big KAP & 65 & $31.0 \%$ & $31.0 \%$ & $100.0 \%$ \\
\hline
\end{tabular}


Note : FP : Tax Facilities; KAE : External Audit Quality.

In this study, there is one moderating variable, namely Tax Facilities, as many as 160 (76.2\%) samples are companies that do not get tariff reduction facilities and as many as 50 $(23.8 \%)$ companies that get tariff reduction facilities. External Auditor Quality is one of the control variables in this study, as many as 145 samples are companies that use small KAPs and as many as 65 samples are companies that use big KAPs.

\subsection{Classical Assumption Test}

The method used in this study is Ordinary Least Square; if we use this method to answer the problem, there are several assumptions that must be met or commonly referred to as the classical assumption test, which consists of error normality, multicollinearity, heteroscedasticity and heteroscedasticity.

\begin{tabular}{cccl} 
& \multicolumn{2}{c}{ Table 3. Classic Assumption Test Results } & \\
\cline { 2 - 3 } Variable & $\begin{array}{c}\text { Multicollinearity } \\
\text { Test }\end{array}$ & Heteroscedasticity Test & Conclusion \\
\cline { 2 - 3 } & VIF & 0.208 & \\
\hline IP & 2.326 & 0.956 & Ho failed to reject \\
IM & 1.804 & 0.244 & Ho failed to reject \\
FP & 22.255 & 0.085 & Ho failed to reject \\
IP*FP & 6.235 & 0.934 & Ho failed to reject \\
IM*FP & 12.364 & 0.138 & Ho failed to reject \\
KI & 1.202 & 0.324 & Ho failed to reject \\
KM & 1.473 & 0.146 & Ho failed to reject \\
KEPINS & 1.713 & 0.456 & Ho failed to reject \\
KAE & 1.626 & & Ho failed to reject \\
Kolmogorov Smirnov & 0,337 & & Ho failed to reject \\
Durbin Watson & 2.120 & &
\end{tabular}

Description : IP : Inventory Intensity; IM : Capital Intensity; FP : Tax Facility ; KI : Independent Commission; KM : Managerial Ownership; KEPINS : Institutional Ownership; KAE : External Audit Quality.

$\mathrm{ETR}=\alpha+\beta 1 \mathrm{IP}+\beta_{2} \mathrm{IM}+\beta_{3} \mathrm{IP} \bullet \mathrm{EP}+\beta_{4} \mathrm{IM} \bullet \mathrm{EP}+\beta_{5} \mathrm{KI}+\beta_{6} \mathrm{KM}+\beta_{7} \mathrm{Kin}+\beta_{8} \mathrm{KAE}+\mathrm{e}$

Table 4. Test Results with Moderation

\begin{tabular}{cccccc}
\hline Variable & Prediction & \multicolumn{3}{c}{ With Moderation } & Conclusion \\
\cline { 3 - 5 } & & Coefficient & $\begin{array}{c}\text { Std. } \\
\text { Error }\end{array}$ & Prob & \\
\hline Constanta & & 0.288 & 0.024 & $0.000^{*}$ & \\
IP & - & -0.074 & 0.057 & $0.099^{* *}$ & Ha accepted \\
IM & + & 0.079 & 0.027 & $0.002^{*}$ & Ha accepted \\
FP & - & -0.059 & 0.036 & 0.106 & Ha rejected \\
IP*FP & + & 0.030 & 0.092 & 0.742 & Ha rejected \\
IM*FP & + & 0.048 & 0.069 & 0.486 & Ha rejected \\
KI & +- & -0.046 & 0.029 & 0.124 & Ha rejected \\
KM & + & -0.053 & 0.034 & 0.117 & Ha rejected \\
KEPINS & - & -0.076 & 0.020 & $0.000^{*}$ & Ha accepted \\
KAE & + & 0.040 & 0.009 & $0.000^{*}$ & Ha accepted \\
R2 Adjust & & & & 0.228 & \\
\hline
\end{tabular}




F stat 0.000

Description : IP : Inventory Intensity; IM : Capital Intensity; FP : Tax Facility ; KI : Independent Commission; KM : Managerial Ownership; KEPINS : Institutional Ownership; KAE : External Audit Quality.

Significance : $* 0.05, * * 0.1$

\section{3 Discussion of Research Results}

\subsubsection{Influence of Inventory Intensity on Effective tax rate.}

The test results show a sig value of $0.099<0.1$ (alpha $10 \%$ ) then Ha is accepted. It is concluded that statistically there is an effect of inventory intensity on the effective tax rate. The results of the hypothesis test show that the inventory intensity variable has a negative effect on the effective tax rate, so that hypothesis $1(\mathrm{H} 1)$ in this study is accepted. This happens because when the company invests in inventory, additional costs will arise. Such as purchase costs, labor costs, raw material costs, and so on. The costs arising from these inventories can reduce the company's profit so that it can reduce the tax burden that must be paid by the company.

The results of this study are like studies conducted [19] and which revealed that inventory intensity has a negative effect on the effective tax rate [2]. Putri and Lautania in their research said that the inventory intensity ratio had a significant negative effect on the effective tax rate [1]. Inefficient inventory evaluation methods can result in high operating costs and can affect the company's income level.

\subsubsection{Effect of Capital Intensity on Effective tax rate.}

The results showed that the sig value was $0.002<0.1$ (alpha 10\%) then Ha was accepted. It is concluded statistically that there is an effect of capital intensity on the effective tax rate. The results of the hypothesis test show that the capital intensity variable has a positive effect on the effective tax rate, so that hypothesis $2(\mathrm{H} 2)$ in this study is accepted. This means that companies that invest in large amounts of fixed assets will have a greater tax burden to be borne. This can happen because it turns out that the management who makes the decision on the depreciation policy is faster than the depreciation time according to taxation, resulting in a positive fiscal correction which causes profit according to taxation to be greater than accounting profit. Thus, the depreciation value cannot suppress the effective tax rate of a company.

This study is in line with and where the intensity of capital is proven to influence the effective tax rate with a positive coefficient direction, meaning that the greater the capital intensity, the higher the effective tax rate [3], [7]. Likewise with the results of Hazir's research, which states that there is a significant positive effect between capital intensity and the effective tax rate [4].

\subsubsection{Tax Facility Moderates by Weakening the Effect of Inventory Intensity on the Effective tax rate}

The results showed that the sig value was $0.742>0.05$ (alpha 5\%) then Ha was rejected. It is concluded that tax facilities are not able to moderate the effect of inventory intensity on the 
effective tax rate. The results of the hypothesis test show that the tax facility cannot moderate by weakening the effect of inventory intensity on the effective tax rate, so hypothesis three (H3) is rejected. High Tax Facility does not affect the high or low influence of inventory intensity on ETR in a company. Companies that get a rate reduction facility certainly do not need to pay a high tax burden; this means that the value of the company's effective tax rate is low. Companies that get these tax facilities tend to try to comply with existing tax regulations so that they are not subject to sanctions that can harm the company.

The results of this study are in line with research conducted by Rahmawati [8], where the $5 \%$ tax rate reduction facility has a significant negative effect on the effective tax rate. Companies that get reduced rates no longer need to carry out tax management to reduce their tax burden. According to Sharma, at all., if the moderating variable (tax facility) does not have a significant effect on the effective tax rate, the moderating result between inventory intensity and tax facilities (IP*FP) does not have a significant effect on the effective tax rate [17]. So that the tax facility as a potential moderator (Homologiser Moderator). This means that the variable has the potential to be a moderating variable.

\subsubsection{Tax Facility Moderates by Strengthening the Effect of Capital Intensity on the Effective tax rate.}

The results showed that the sig value was $0.486>0.05$ (alpha $5 \%$ ) then Ha was rejected. It is concluded that tax facilities are not able to moderate the effect of capital intensity on the effective tax rate. The results of hypothesis testing indicate that tax facilities cannot moderate by strengthening the effect of capital intensity on the effective tax rate, so hypothesis four (H4) is rejected. High Tax Facility does not affect the high or low effect of capital intensity on the effective tax rate on a company. Companies that get a rate reduction facility certainly do not need to pay a high tax burden; this means that the value of the company's effective tax rate is low. Companies that get these tax facilities tend to try to comply with existing tax regulations so that they are not subject to sanctions that can harm the company.

The results of this study are in line with research conducted by Rahmawati, where the 5\% tax rate reduction facility has a significant negative effect on the effective tax rate [8]. Companies that get reduced rates no longer need to carry out tax management to reduce their tax burden. According to Sharma, at all., if the moderating variable (tax facility) does not have a significant effect on the effective tax rate, the moderating result between capital intensity and tax facilities (IM*FP) does not have a significant effect on the effective tax rate [17]. So that the tax facility as a potential moderator (Homologiser Moderator). This means that the variable has the potential to be a moderating variable.

Control Variable Test Results. The results of the control variable test show that the independent commissioner has no effect on the effective tax rate. This result is in line with [18]. The existing independent commissioners only comply with existing regulations and do not have an impact on company policies, one of which is the policy on taxation. Furthermore, the managerial ownership variable has no effect on the effective tax rate. This result is in line with, which states that the more management owns shares, the greater the management's effort to carry out effective tax management which is believed to reduce the value of the effective tax rate [19].

While the variable of institutional ownership has a negative effect on the effective tax rate. These results are in line with research [20]. This can happen because institutional shareholders try to supervise the company's management in carrying out company policies, one of which is tax policy. This supervision is carried out so that the company generates large profits, but the 
tax burden remains low. The external auditor quality variable has a positive effect on the effective tax rate. This result is in line with research [15]. Companies whose financial statements are audited by the big four public accounting firm (KAP) tend not to manipulate profits for tax purposes. That means the tax that the company must pay is in accordance with the actual situation.

\section{Conclusions}

The inventory intensity variable has a negative effect, and the capital intensity has a positive effect on the effective tax rate. While the tax facility is not proven as a moderating variable of the effect of inventory intensity on the effective tax rate. Tax facilities are not proven as a moderating variable of the effect of capital intensity on the effective tax rate. So that the tax facility as a potential moderator (Homologiser Moderator). This means that the variable has the potential to be a moderating variable. The control variables in the form of independent commissioners and managerial ownership are not proven to have a significant effect on the effective tax rate. While the control variables in the form of institutional ownership and the quality of external auditors are proven to have a significant effect on the effective tax rate.

\section{Implications and Suggestions}

Based on the conclusions from the research results described above, the implications that can be used for theory and policy development for related parties are theoretical implications, which are expected to increase insight and knowledge for academics, especially regarding the factors that affect the effective tax rate. For investors, it is hoped that it can be used as a reference in making investments, considering the taxes that are complied with by the company. Suggestions for further researchers are expected to be used as a reference related to the factors that affect the effective tax rate.

\section{References}

[1] C. L. Putri dan M. F. Lautania, "Pengaruh Capital Intensity Ratio, Inventory Intensity Ratio, Ownership Strucutre dan Profitability Terhadap Effective Tax Rate (ETR)(Studi pada Perusahaan Manufaktur yang Terdaftar di Bursa Efek Indonesia Tahun 20112014)," J. Ilm. Mhs. Ekon. Akunt., vol. 1, no. 1, hlm. 101-119, 2016.

[2] Y. M. Salaudeen dan R. O. Akano, "Non-Linearity in Determinants of Corporate Effective tax rate: Further Evidence from Nigeria," Int. J. Econ. Financ. Res., vol. 4, no. 3, hlm. 56-63, 2018.

[3] S. E. Putri, "Pengaruh Ukuran Perusahaan, Return on Asset(ROA), Leverage dan Intensitas Modal Terhadap Tarif Pajak Efektif," J. Online Mhs. Fak. Ekon., vol. 3, no. 1, hlm. 1506-1519, 2016.

[4] A. Hazır, "Determinants of Effective tax rates in Turkey," J. Res. Bus., vol. 4, no. 1, hlm. 35-45, 2019, doi: doi.org/10.23892/jrb.2019453293.

[5] R. Steven, V. Ratnawati, dan Julita, "Analisis Faktor Yang Mempengaruhi Pajak Dengan Indikator Tarif Pajak Efektif (Studi Empiris Pada Perusahaan Barang Konsumsi Yang Terdaftar Di Bursa Efek Indonesia Pada Tahun 2011-2015),” J. Ekon., 
vol. 26, no. 2, hlm. 122-137, 2018.

[6] R. Wulansari, "Pengaruh Karakteristik Corporate Governance Terhadap Effective tax rate (ETR) (Studi Empiris Pada Perusahaan Perbankan yang Terdaftar di BEI Tahun 2011-2013)," J. Online Mhs. Fak. Ekon., vol. 2, no. 2, hlm. 1-15, 2015.

[7] D. Kumalasari dan A. Wahyudin, "Pengaruh Leverage dan Intensitas Modal terhadap Effective Tax Rate (ETR) dengan Profitabilitas sebagai Variabel Moderating," $J$. Akunt. Keuang. dan Audit., vol. 2, no. 1, hlm. 53-66, 2020.

[8] H. Rahmawati, "Pengaruh Ukuran Perusahaan, Profitabilitas, Leverage, Fasilitas Perpajakan, dan Komisaris Independen terhadap Manajemen Pajak pada Perusahaan Manufaktur yang terdaftar di Bursa Efek Indonesia (BEI)," J. Online Mhs. Fak. Ekon., vol. 4, no. 1, hlm. 2907-2921, 2017.

[9] D. Indradi dan M. M. Setyahadi, "Pengaruh Transaksi Hubungan Istimewa Terhadap Tarif Pajak Efektif dengan Leverage sebagai Variabel Moderating," J. Akunt. Berkelanjutan Indones., vol. 2, no. 3, hlm. 375-392, 2019.

[10] N. Sabli dan R. Noor, "Tax Planning and Corporate Governance," 2012.

[11] B. N. L. Putri dan S. Rachmawati, "Analisis Financial Distress dan Free Cash Flow dengan Proporsi Dewan Komisaris Independen sebagai Variabel Moderasi Terhadap Manajemen Laba,” J. Keuang. Dan Perbank., vol. 14, no. 2, hlm. 54-61, 2018.

[12] I. Setiawan dan A. Nilasari, "Pengaruh Good Corporate Governance Dan Transaksi Hubungan Istimewa Terhadap Effective Tax Rate," J. Renaiss., vol. 4, no. 2, hlm. 583598, 2019.

[13] E. Murwaningsari, "Hubungan Corporate Governance, Corporate Social Responsibilities dan Corporate Financial Performance Dalam Satu Continuum," $J$. Akunt. Dan Keuang., vol. 11, no. 1, hlm. 30-41, 2009, doi: doi.org/10.9744/jak.11.1.pp.30-41.

[14] Y. C. Wijayanti dan N. K. L. A. Merkusiwati, "Pengaruh Proporsi Komisaris Independen, Kepemilikan Institusional, Leverage, dan Ukuran Perusahaan Pada Penghindaran Pajak," E-Jurnal Akunt. Univ. Udayana, vol. 20, no. 1, hlm. 699-728, 2017.

[15] Y. Sudaryo, D. Sjarif, N. A. Sofiati, dan P. Christian, Keuangan di Era Otonomi Daerah, 1 ed. Yogyakarta: Andi Offset, 2018.

[16] C. P. Gultom, "Pengaruh Good Corporate Governance Terhadap Tax Avoidance (Studi Empiris pada Perusahaan Pertanian yang terdaftar Di Bursa Efek Indonesia Periode Tahun 2013-2015)," J. Online Mhs. Fak. Ekon., vol. 4, no. 2, hlm. 7395-7409, 2017.

[17] S. Sharma, R. M. Durand, dan O. Gur-Arie, "Identification and Analysis of Moderator Variables," J. Mark. Res., vol. 18, hlm. 291-300, 1981, doi: dx.doi.org/10.2307/3150970.

[18] Y. Susilowati, R. Widyawati, dan Nuraini, "Pengaruh Ukuran Perusahaan, Leverage, Profitabilitas, Capital Intensity Ratio, dan Komisaris Independen Terhadap Effective tax rate," in Prosiding Seminar Nasional Multi Disiplin Ilmu \& Call For Papers Unisbank (Sendi_U), 2018, hlm. 796-804.

[19] A. Boussaidi dan M. Hamed, "The Impact Of Governance Mechanisms On Tax Aggressiveness: Empirical Evidence From Tunisian Context," J. Asian Bus. Strateg., vol. 5, hlm. 1-12, 2015.

[20] R. B. Charisma dan S. Dwimulyani, "Pengaruh Struktur Kepemilikan Terhadap Tindakan Penghindaran Pajak Dengan Kualitas Audit Sebagai Variabel Moderating," in Prosiding Seminar Nasional Pakar, 2019, hlm. 2-32. 